\title{
Dil Üzerinden Hukuk ve İdeoloji İlişkisinin Bir Değerlendirilmesi
}

Öz: Dil, saydam ve şeffaf bir araç olmayıp, gerçeğin kuruluşunda bulunan toplumsal bir pratiktir. Dolayısıyla toplumsal düşünce ile toplumsal gerçeklik arasındaki ilişkiler, dil ve ideoloji arasındaki ilişkiler zemininde tartışmaya açılır. Toplumsal düşünce ve gerçekliğimizin dil aracılığıyla somutlaştığı alanlardan biri de hukuktur. Bu bakımdan hukuk da sahip olduğu anlamsal yapı ve uygulamada kullandığı metodlar dolayısıyla dil üzerinden ideoloji tartışmasına taşınabilir. $\mathrm{Bu}$ düşünce doğrultusunda öncelikle dilin ideoloji ile olan ilişkisini ortaya koyabilmek için, yapısalcı ve post yapısalcı kuramların üzerinde durdukları söylem ve metin kavramlarına bakmaya çalışacağız. Burada, anlamların sabitlenmesi ve yorum olanaklarının incelenmesi ile dilin etkilerinin göz önünde tutulmadan tanımlanabilecek yalın bir gerçeklik alanı olmadığına ișaret etmeye çalışacağız. $\mathrm{Bu}$ noktadaki asıl ilgimiz, anlam ve yorum üzerinden açımlanan dil ve ideoloji tartışmalarındaki ortak düşünceye yönelik olacaktır. Nitekim burada asıl amacımız, anlamların çoğunlukla otorite ya da güç odaklarının lehine harekete geçirildiğini, anlamın belirlenmesindeki mücadelenin çoğunlukla bu otoritenin ya da güç odaklarının lehine sonuçlanmakta olduğunu ortaya koymak olacaktır. Ardından, hukuk dilinin içindeki anlamlar ve yorum olanaklarına yönelerek, bu olanakların otorite ya da güç odaklarıyla olan muhtemel ilişkisini incelemeye geçeceğiz. Bu ilişkiler silsilesini ise hem hukukun oluşturulmasında anlamsal çerçevenin bilinçli kurulumuna hem de bu çerçeve içerisinde yorumun olanak tanıdığı mümkün bir anlamın otorite lehine nasıl harekete geçirilebildiğini gösteren somut bir örnek üzerinden bağlamına oturtmaya çalışacağız. Sonuç kısmında ise, genel bir değerlendirme kapsamında, 'hukuk, dil, ideoloji' üçlemesinde dilin sunacağı imkan ve güçlükler üzerinde durulacaktır. Bu doğrultuda da, hukuk sistemindeki anlamsal yapının otoritenin ya da güç odaklarının lehine harekete geçirilmesini önleyecek unsurların neler olabileceği tartışılacak ve onun otoritenin lehine sonuçlanmış bir mücadelenin sonucu olarak değil, dilsel bir uzlaşımın ürünü olarak ortaya çıkması gerekliliği vurgulanacaktır.

Anahtar Kelimeler: Dil, Anlam, Yorum, İdeoloji, Hukuk. 


\title{
An Evaluation of Law and Ideology Relationship over Language
}

\begin{abstract}
Language is not a transparent and clear instrument, but is a societal practice in the establishment of reality. Therefore, the relationships between societal thinking and societal reality are opened up for discussion on the ground of the relationships of language and ideology. One of the fields in which our societal thinking and reality become concrete through language is law. From this point of view, law can also be moved to the ideological discussion over language thanks to the semantic structure it has and the methods it uses in practice. In line with this thinking, we will try to analyze the concepts of expression and text on which structuralist and post-structuralist theories put emphasis. Here, we will try to point that there is not a simple reality field to be defined without bearing the effects of language in mind through fixing the meanings and examining the chances of interpretations. Our real interest at this point will be towards the common thinking in language and ideology discussions annotated over meaning and interpretation. However, our real aim here will be to reveal that meanings are mostly motivated in favor of authority or power groups and that the struggle in the determination of meaning results mostly in favor of such authority or power groups. Then, we will move on to examining the possible relationship of these choices with authority or power groups by tending to the meaning and interpretation choices in the language of law. We will try to contextualize this sequence of relationships both over the conscious establishment of semantic frame in the formation of law and over a concrete example showing how a possible meaning allowed by a interpretation in this frame can be motivated in favor of authority. In the conclusion part, the possibilities and difficulties caused by language will be emphasized in the trilogy of "law, language, ideology" in the context of a general evaluation. Accordingly, it will be discussed what the factors are that will prevent semantic structure from being motivated in favor of authority or power groups, and the necessity will be emphasized that this semantic structure should emerge not as a result of the struggle having resulted in favor of authority but as a product of a language reconciliation.
\end{abstract}

Keywords: Language, Meaning, Interpretation, Ideology, Law.

\section{Giriş}

Dil, tüm dolayımların dolayımcısı olarak anlamak, anlatmak, kavramak ve kavramsallaştırmak için kullandığımız biricik aracımızdır. Gerek ideoloji üzerine yapılacak her türlü tartışmalarda, gerekse de adaleti sağlayabilmek için yürütülen muhakeme ve uygulamalarda ayrıca ele alınması gereken bir organon olarak da karşımıza çıkar "dil”. Çünkü o, aynı zamanda hem kuran hem kurulabilendir.

Öyle ki, ideoloji kavramı hangi düşünsel perspektiften ele alınırsa alınsın, ortaya koymak istediği düşünsel dönüşüm ve paradigma değișimlerini, öncelikle dil, anlam, söylem ve metin ile kuracağı ilişkiler düzlemiyle belirlenmeye çalışılır. $\mathrm{Bu}$ bakımdan ideolojinin de tıpkı kültür gibi, toplumsal yaşamın kendisiyle ilgili 
düşüncelerin, anlamların ve sembolik temsillerin alanına işaret eden bir kavram olduğu hemen göze çarpar. İdeoloji, kültürle olan farkını ise, kültürün anlam ve sembolik temsiller üzerinde bir ortaklığa, paydaşlığa işaret ettiği yerde, kendisini farklı toplumsal anlam ve değerlerin çatıştığı bir alanda oluşan toplumsal bir düşünce olarak konumlamasıyla ortaya koyar. Bu anlamda ideoloji, farklı bilinç formlarının farklı anlamlar ve yorumlar çerçevesinde yaratmış olduğu çatışkılı bir duruma gönderme yapar. Bu bakımdan toplumsal pratiğin belli bir tarzda belirlenme çabası olarak da işaret edebileceğimiz ideoloji, var olanı tanımlama ve yorumlama sorunu üzerinden "dilsel" bir kontekste yerleşir.

$\mathrm{Bu}$ dilsel bağlama, açıklama, tanımlama ve yorumlama sorunu üzerinden yerleşen bir diğer pratik ise hukuk'tur. Her şeyden önce toplumsal bir olay olarak karşımızda duran hukuk, pozitif hukuk bağlamında "belirli bir topluma" ait olan, insan yapımı normatif bir alana işaret eden "buyruklar, yani normlar", "mahkeme kararları" olarak ifade bulabilir (Wacks 2017: XV). Bu söz konusu hukuksal normlar ve mahkeme kararları, bir hukuk metni içerisinde muhafaza edilir ve onların, tekil olaylar karşısında hukuk uygulayıcılarının verecekleri kararlar kapsamında temel bir belirleyicilikleri bulunur. Tıpkı toplumun kendisi gibi tarihi bir varlığa sahip olan hukukun, bu hukuk metinleri içerisinde kendi tarihi varlığını açımladığına tanık oluruz. Bunu mümkün kılan, hukuk dilinin de, insanın toplumsal pratiğinin belli bir tanımlanma ve yorumlanma uğrağı olarak ortaya çıkıyor olmasıdır. Hukuk uygulayıcılarının belli bir hukuksal metni temele almalarına karşın, hukukun yine de belli bir uğraktaki toplumsal pratiğin, yani var olanın belli bir tanımlanma ve yorumlanmasıyla ilişskili olarak karşımıza çıkmasının ise birkaç temel nedeni vardır. Bunlardan ilki, hukuksal metnin dilsel olma özelliğinden kaynaklanan ve hukukun diline de sirayet eden "dilsel belirsizlik" mefhumu olarak ifade edilebilir. Özellikle H. L. A. Hart'ın (1994) hukuka ilişkin çalışmalarının odak noktalarından birini oluşturan bu sorun, onun tarafından "dilin açık dokulu olduğu" savından hareketle, hukuksal kavramların, normların ve kuralların birden çok açık anlamının bulunduğu ve dolayısıyla da söz konusu kavramların vakaya 
uygun düşüp düşmediğinin belli olmadığı "yarı gölgesel” durumların daima bulunduğu şeklinde ifade bulur. Böylece Hart, hukuku, ancak bir topluluğun mevcut sosyal pratiklerinin betimlenmesiyle anlaşılabilecek toplumsal bir fenomen olarak ortaya koymak gerekliliğine dikkat çeker. Bunun temel nedeni, açıktır ki, toplumsal anlam ve değerlerin belli bir toplumsal pratiğin ürünü olarak görülmesidir. Bu noktada Hart'ın, hukuk ile toplum arasında kurduğu ilişkiyi dilin anlam boyutu üzerinden tesis ettiğine dikkat çekelim ve hukukun yorum bağlamında dil ile kurduğu zorunlu ilişkinin ikinci bir nedenine bakmaya çalışalım.

Hukuk uygulayıcılarının, hukuki bir süreçte "hukuk metnini" ele aldıkları tekil bir olaya uyarlama zorunlulukları, dil ve hukuku "yorum" üzerinden birbirine bağlayacak ikinci bir neden olarak karşımıza çıkar. Yazılı haldeki hukuk metninin kendine özgü hukuksal bir davaya uyarlanması, hukuk uygulayıcılarının söz konusu dava ile ilgili kararlarını vermek için zorunludur ve bunu, ancak bu yazılı metni yorumlamak suretiyle yapabilirler. Her davanın kendine özel bir durumu olduğu göz önünde tutulduğunda, hukuk uygulayıcılarının, özellikle de hakimlerin yazılı hukuk metinlerini “yorumlama” gibi bir zorunlulukla karşı karşıya kaldıkları söylenebilir. $\mathrm{Bu}$ bakımdan, hukuk metninin, yani yasanın yorumlanmasını, hukukun uygulanması açısından bir olmazsa olmaz olarak görmek ve değerlendirmek gerekir. Nitekim hukuk ve yorumu dil üzerinden birbirine bağlayan bir üçüncü nedenin de, hukuk metninin oluşturulması esnasında tüm olası durumların ön görülememesi olduğu dikkate alındığında, yasaların zorunlulukla her bir davada belli ölçülerde de olsa zaten yoruma açık olması gerektiğini görmek gerekir. Hukuka ve hukuksal metnin doğasına ilişkin tüm bu belirlenimler göz önünde tutulduğunda da, hukuk uygulayıcılarının adalet ile ilgili görüşleri, yani adil, doğru ve hakkaniyetli olanın ne olduğuna dair betimlemeleri ve düşünceleri doğrultusunda, her zaman açık uçlu olabilen yasaların içeriğini doldurma yoluna gittikleri söylenebilir. Hatta Dworkin'in iddia ettiği gibi, hukuk uygulayıcıları adalet ve hukukla ilgili yaptıkları betimleme ve sahip oldukları görüşlerin doğruluğuna duydukları sarsılmaz inanç dolayısıyla, bu yorumun tek 
doğru yorum olduğuna bile inanırlar. Bu noktada söz konusu yorumun tek doğru yorum olup olmayacağı tartışmasına girmeden, şuna dikkat çekmek gerekir ki hukuk uygulayıcısı, temelde bir toplumsal pratik olarak belirlediğimiz hukuku uygularken, kendisine bu toplumsal pratiği düzenleme işlevi verilmiş olmasından dolayı, bu toplumsal pratiği temele alarak iş görmek durumunda kalır. Bir başka ifade ile toplumsal pratiğin olağan devamı, yani o anki kamusal duyarlılıkların güvencesi olmak adına hukuk uygulayıcılarının, hukuksal bir davaya bir hukuk metnini uyarlarken giriştikleri yorum eyleminde, bu toplumsal pratiğin kendini gösterdiği ve yarattığı anlamsal çerçeve ve betimlemeleri temele almaları kaçınılmazdır da denilebilir.

Bir hukuk metninin yorumlanmasında temele alınan bu toplumsal pratiğin başat anlamsal ve betimsel çerçevesinin, metne bağlı olmayan hukuksal yorum metotlarında da aynı şekilde iş göreceği aşikardır. Sonuçta bir hukuk uygulayıcısının tarihsel yorum metodunda olduğu gibi yasa koyucunun niyetini soruştururken ya da amaçsal yorum metodunda hukuki kurum, norm ya da işlemlerin amaçlarını değerlendirirken, yine, sonuçcu yorum metodunda olduğu gibi aynı normun farklı yorumlarını karşılaştırırken ve nihayetinde menfaatler içtihadı metodunu kullanırken menfaatleri dengelenmek üzere yorum metoduna başvurduğunda (Manko 2016: 3), içinde bulunduğu toplumun mevcut anlamsal ve betimsel çerçevelerini temele almak ya da en azından onları yok saymamak durumundadır. Nitekim bir hukuk uygulayıcısının, hukuk normlarındaki bir boşluğu doldurmak üzere, ister bir hukuk metnini temele alarak isterse de ona bağımlı olmadan hukuku uygulamak için yorum metoduna başvurduğunda, anlamak, anlaşılmak, kavramak ve kavramsallaştırmak adına belli ölçülerde bile olsa mutlaka toplumsal pratiğin belirlediği anlamsal çerçevenin içerisinden hareket etmesi gerektiği açıktır.

Dolayısıyla toplumsal pratiğin, belli bir tarzda belirlenme çabası olarak işaret ettiğimiz ideolojinin, en azından var olanı ya da bir olguyu tanımlama ve 
betimleme çabası dolayısıyla hukukla zorunlu olarak ortak bir zeminde yollarının kesiştikleri söylenebilir. Bu ortak zemin şüphesiz ki bize, hukukun toplumun bu belli tarzda belirlenmiş pratiği ile olan ilişkilerini sorgulama hakkı tanır ki, bu soru da daima başka sorulara gebedir.

Çalışmamız bu soruları ortaya koyabilmek üzere, hukukun ideoloji ile ortak paydası olan dil üzerinden, onların aralarındaki ilişkiyi sorunsallaştırmaya çalışacaktır. $\mathrm{Bu}$ bakımdan dil üzerinden konuya yaklaşmayı denerken, hukukçuların hem metne bağlı kalarak yaptıkları yorum pratiğinin hem de hukukun ne olduğunu söylemekten ibaret olan toplumsal pratiğini ifade eden (lafzi) yorumun, yani hukukun içindeki söylem türünün dikkate alınacağını belirtelim. Ayrıca bu çalışma boyunca temelde tutacağımız ana düşünce, "dilin toplumsal yaşamın biçimlendiricisi olduğu" şeklindeki Wittgensteincı ve Austinci temel sav olacaktır. Dolayısıyla bu düşüncenin ışığında, gerçekliğin toplumsal dilin içine gömülü olduğu, dilin etkileri göz önünde tutulmadan tanımlanabilecek yalın bir gerçeklik alanı olmadığı fikrinde birleșen yapısalcı ve post yapısalcı kuramların tartışmaya açtıkları söylem ve metin kavramları bizim için de konuyu ele alırken temel bir yol gösterici niteliğinde olacaktır. Bir başka ifade ile dil üzerine yapılan söylem ve metin tartışmalarının ideoloji kuramlarına açtığı alanda, dil ile olan ilişkisi bağlamında hukukun durumunu incelemeye çalışacağız da denilebilir. Dolayısıyla ilk aşamada, varolanın, olguların, kısacası tüm gerçekliğin tanımlanmasında, anlamlandırılmasında ve yorumlanmasında dilin iş başında olduğunu, aslında gerçeklik denilen şeyin insanın toplumsal pratiğinin belli bir tanımlanma uğrağına karşılık geldiğini, bu bakımdan hukuk uygulayıcılarının da kullandıkları yorum metodu dolayısıyla dilin etkilerinden muaf olmadıklarını göstermeyi amaçlamaktayız. Bu tartışmanın açık kılmasını beklediğimiz bir diğer önemli nokta da, anlamların çoğunlukla otorite ya da güç odaklarının lehine harekete geçirildiği, anlamın belirlenmesindeki mücadelenin çoğunlukla bu otoritenin ya da güç odaklarının lehine sonuçlanmakta olduğu olacak. Bu hususları açık kıldıktan sonra, hukuk dilinin içindeki anlamlar ve yorum olanaklarına 
yönelerek, bu olanakların otorite ya da güç odaklarıyla olan muhtemel ilişkisini incelemeye geçeceğiz. Son olarak ise, bu akıl yürütme zincirini, hem hukukun oluşturulmasında anlamsal çerçevenin bilinçli kurulumuna hem de bu çerçeve içerisinde yorumun olanak tanıdığı mümkün bir anlamın otorite lehine nasıl harekete geçirilebildiğini gösteren somut bir örnek üzerinden bağlamına oturtmaya çalışacağız.

\section{Söylem, Metin ve İdeoloji: Bir Toplumu Biçimlendirmeye Doğru}

Toplumsal düşünce ile toplumsal gerçeklik arasındaki ilişki sorunu dolayısıyla dil'e yönelmek durumunda kalan ideoloji tartışmalarının büyük bir kısmının hem yapısalcı hem de post-yapısalcılarca kabul gören daha çok anlamlar düzleminde yürütülen söylem ve yorum/yorumsama düzleminde yürütülen metin kavramları kapsamında yürütüldüğüne tanık oluruz. Bu, ideolojinin özcü bir anlayıştan kendini sıyırarak, anlam ve söylem düzeyleri üzerinden gerçeğin nasıl inşa edildiğini araştırmaya başladığı noktadan itibaren önümüze açllan bir ufuk olmuştur. Bu noktadan itibaren ideolojinin toplumsal gerçeklikle kurduğu ilişkiler, söylem ve metin üzerinden, anlam ve yorum kavramları irdelenerek ele alınma yoluna gidilmiştir.

İdeoloji ve dil arasında kurulan bu ilişkiyi izleyebilmek içinse dilbilimdeki gelişmeleri takip etmemiz gerekir. Nitekim bu seyirde göreceğimiz, dilin saydam ve şeffaf bir araç olduğu düşüncesinden, onun gerçeğin kuruluşunda bulunan bir toplumsal pratik olarak tanımlanmaya doğru evrildiği olacaktır.

\section{1. Toplumsalın Yeni Bir Gözle Değerlendirilmesine Doğru: Söylem ve Anlamın Değişkenliği}

Toplumsal anlamı, dilin doğru ve kurallara uygun kullanımının bir sonucu olarak düşünen Klasik dilbilimcilerin aksine, Saussure, toplumsal anlamı, gösterge'nin gösteren ve gösterilen öğeleri arasındaki bir ilişki olarak tanımlar (Sancar 2014: 105). Bir başka ifade ile bu görüş, dikkatini dilin öğeleri arasındaki ilişkiye yöneltir ve onları eşsüremli olarak inceleme yolunu seçer. Ancak şunu 
belirtmeden de geçmemek gerekir ki, Saussure dil ve söz olarak ikiye ayırdığı dil yetisi anlayışı doğrultusunda, sözün olumsallığını bir kenara bırakarak, dilin bireysel ve tarihsel yanlarının bilimsel incelemeye elverişli bir dizge olarak kurulabileceğine inanır. Bu bakımdan Saussure'ün ortaya koyduğu hali ile bu dil anlayışı, dış dünyaya ve onu konuşan insanların gerçekliğine kendini kapatarak, kendi gerçekliğini kendisinde taşıyan kapalı bir sistem halini alır. Açıktır ki böyle bir dil anlayışında, dili kullananlar ise, sadece basit birtakım seçme ve yanyana dizme işlemlerini yapmaktan öteye gidemeyen failler olarak kalır.

Anlamlandırma ediminin açıklamasını, dilsel öğelerin eşsüremli ilişkisinden çıkarsayan Saussure'ün ortaya koyduğu bu göstergebilim anlayışı, kısa bir zaman içerisinde ideolojinin toplumsal pratiklerle ilişkili bir kurucu öğe olarak ele alınması sürecinde verimli bir alan haline dönüşür. Nitekim Saussure'ün ardından, Barthes'in düz anlam/yan anlam ayrımıyla birlikte, göstergebilimde ilgi gösterenlerden (signifiers), gösterilenlere (signified) doğru yönelir. Dant'ın da (1991: 99-110) dikkat çektiği gibi, Barthes'in göstergebilimdeki önemi, onun bizi dilin yapısının belirlediği açık anlamlar bulunduğu fikrinden uzaklaştırmasıdır. Nitekim yan anlam kavramı ile ilginin gösterilenlere doğru kayması, yorum olanakları üzerinde dilde yeni bir düşünme alanı açar. $\mathrm{Bu}$ noktada göstergebilimdeki tartışmaların, klasik dilbilimcilerinin dilin yapısının, yani dilin kurallarının doğru uygulanmasının bir sonucu olarak gördükleri açık anlamdan, gösterilenlerin sahip olduğu düşünülen gizil ve ortaya çıkarılması gereken gizil anlamlara, onların işleyiş düzenlerine, yani yorumun olanaklarını araştırmaya doğru evrildiği gözlenir. Dolayısıyla dildeki klasik yaklaşım tarzının toplumsal olguları dil gibi çözümlemeyi tercih ettiği noktada, artık söylem çözümlemelerinin üzerinden toplumsalın yeni bir gözle anlaşılması tercih edilmeye başlanır. Söylem çözümlemelerinin yarattığı en önemli farkındalık, dilin, birey ve kurumların davranışlarına yön veren düşüncelerini oluşturan, eş deyişle toplumsal yaşamın biçimlendirilmesini sağlayan önemli bir araç olduğudur. 
Bu noktada dilin basit bir iletişim aracı olmaktan çok, toplumsal yaşamın bir biçimlendiricisi olarak değer kazanması, Wittgenstein ve Austin gibi düşünürlerce dilin toplumsal karakterinin ve yaratmış olduğu etkenlik olanağının ne olduğunun araştırılması ve öneminin ortaya konulması ile ilgilidir. Dilde, özellikle konuşmada ortaya çıkan bildirimin, bir edim olarak görülmeye başlanması, konuşmanın toplumsal bakımdan neyin söylenebilir ve söylenmesi olanaklı olduğunu bağlamsallaştıran bir pratik olarak tanımlanmasıyla sonuçlanır (Sancar 2014: 105106). Böylece söylem kavramı, dil üzerindeki tartışmaların merkezine oturur. Ancak bu tartışmaların söylem üzerinde homojen bir varsayımdan hareket etmediğine de dikkat çekmek gerekir. Nitekim söyleme ilişkin yürütülen tartışmalar, kendilerini farklı yaklaşımlarda ve farklı yöntemlerle açımlarlar. Bu durum, söylem tartışmalarını izlemekte birtakım güçlükler doğursa da, yine de tüm bu yaklaşımların anlam, bağlam ve toplum ile kurduğu ilişkiler noktasında ortak bir yön taşımaları ve söyleme toplumun temel biçimlendiricisi olma işlevini yüklemiş olmaları bakımından, bize üzerinde durabileceğimiz ortak bir zemin sunuyor olduklarını da ifade edelim. Nihayetinde Thompson'ın (1984: 73-74) da ifade ettiği gibi, farklı yaklaşım ve yöntemlerle açıklanma yoluna gidilse de, bu tartışmalarda anlamın söylem içerisindeki oluşumu ve akışkanlığı bağlamında ortak bir düşüncenin hakimiyeti söz konusudur ve ideoloji tartışmaları da söylem içerisinde oluşturulan bu anlamların belli bir grup, cemaat ya da bireyin menfaatine olmak üzere nasıl oluşturulduğu ve şekillendirildiği üzerinde yoğunlaşmaktadır. Burada dikkat çekilmesi gereken husus, Saussure'ün “söz"ü ele alırken onu bireysellik ekseninde açımlarken, toplumsal bir çözümleme aracı haline gelen söylem ile birlikte, söz'ün toplumsal kullanımının ön plana çıkartılmakta olduğudur. Ayrıca söylem çözümlemeleri, dil düzleminde de ilgilerini söz ile birlikte cümleye, cümleden de sözce ve metine doğru genişletir. Anlamın dil içerisinde hareket etme özelliğine sahip olduğu ana savını temele alan söylem yaklaşımları böylece, anlamın sabitliğini değil, değişkenliğini savunmaya ve bu değişkenliğin sağladığı bir olanak olarak da yorum'un üzerinde durmaya başlarlar. 
Söylem çözümlemelerinde özellikle sözcelemin (enunciation) üzerinde durulması, dile özgü yeni farkındalıklara kapı aralar. Nitekim sözcelem üzerindeki incelemeler, dilin yapısı üzerindeki çalışmaları arka plana iterek, sözün bildirişim özellikleri üzerine bir düşünüme alanı açar. Böylece bir bildirişimde belirleyici olan unsurlar, konuşmanın yapıldığı yer, zaman ve şartları olarak ifade bulur. Bu noktada söylem çözümlemesinin, bu unsurlar gereği, bireysel dil edimlerince yaratılan anlam akışlarına yönelmiş olduğunu da görmek gerekir. Dolayısıyla anlam akışlarının belli bir bağlam ve durum içerisinde gerçekleşiyor olması, söylem çözümlemelerinin ana ilgisi haline gelir. Eş deyişle, anlamın nasıl yaratılıyor olduğu, kime yönelik olarak ortaya konulduğu, neyi ifade ediyor olduğu ve nasıl bir etki yarattığı gibi sorular, söylem çözümlemesinin temeline yerleşir. Bu türden soruları yanıtlamak için söylem çözümlemecilerinin yanıt vermeleri gereken ilk soru dolayısıyla, öncelikle, söylemin hangi toplumsal koşullar altında gerçekleşmekte olduğu sorusu olmuştur. Nitekim ideoloji, onun içinde anlamını bir doğrultuya yönlendirme-tahakküm ilişkilerini yaratacak ve çoğaltacak etkiyi yaratma olarak tanımlanınca (Sancar 2014: 136), bu etkileri kuran bir odak noktası olarak iktidar kavramına yönelinmiş ve söylem ile iktidar arasındaki ilişkiler sorunsallaştırılmaya başlanmıştır. Böylece de iktidar ilişkilerinin, dilsel ve simgesel iletişim içinde nasıl bir mekanizma ile işlediği konusu bir açıklığa kavuşturulmaya çalışılmıştır. Bu sorunun açımlanmasını sonraya öteleyerek, şimdi ana ilgisini konuşma edimine değil de, metine ve metindeki anlam olanakları üzerinden yoruma/yorumsamaya yönelten görüşe bakarak, dilbilimin ortaya koyduğu bu yeni olanağın toplumsal pratikleri anlamlandırma/simgeleme üzerindeki etkilerinin neler olabileceğine bakmaya çalışalım.

\section{2. Toplumsal Pratikleri Anlamlandırmada Yeni Bir Olanak: Metin ve Yorum Olanakları}

Metin kavramını bir araştırma nesnesi olarak ele alan düşünürler, öncelikle bu araştırma nesnesinin söylemle olan farkını ortaya koymak ve ona özgü olanakları böylece ön plana çıkarmak istemiş görünürler. Bu düşünürlerden en 
önemlilerinden biri, Paul Ricoeur'dür. Onun da metin incelemesini temele alırken öncelikle söylem ve metin üzerinden bir ayrıma giderek, metnin kendine özgü olarak ortaya koyacağı “yorum” olanaklarını ele almak istediği görülür. Ricoeur’ün (1990) söylem ve metin üzerinde yaptığı bu ayrım, sözlü söylem ile yazıya dökülmüş söylenen arasındaki ayrışmayı ve her ikisinin de toplumsal pratiği biçimlendirmede kullandığı unsur ve yöntemlerin farklılığını anlamak açısından oldukça değerlidir. Dolayısıyla kısaca üzerinde durmak faydalı olacaktır. Ricoeur'ün söylem ve metin arasındaki farkları ortaya koyarken üzerinde durduğu temel soru, söylemin ortaya çıktığı konuşma'nın yazılı hale getirildiğinde nasıl bir değişime uğradığıdır. Bu temel soruya verilebilecek yanıtlar doğrultusunda, Ricoeur öncelikle söylemin zamansal olarak belli bir uğrağı olduğuna, yani onun zamansal olarak "şimdi”nin içinde gerçekleştiğine dikkat çeker. Öte yandan söylem, her zaman bir özneye sahiptir ve söylem anında, yani konuşulan bağlamda konuşana, yani söylemin öznesine anlık bir geri dönüş vermek mümkündür. Söylem, simgeleştirme işlevini üstlenerek, dünyayla ilişkili bir şeyi betimlemek, anlatmak ve temsil etmek arzusunda olduğu için, her zaman bir şey hakkındadır da. Ayrıca söylemde konuşan öznenin her zaman bir muhatabı vardır ve bu muhatapla sadece iletişim amaçlı olarak konuşmaya girilmez. Buradaki amacın daha çok konuşulan şey hakkındaki düşüncelerin aktarımı, eş deyişle mesajların alınıp verilmesi olduğu düşünülür. Böylece Ricoeur'ün belli bir özne, belli bir an ve belli bir muhatap özelliği ile söylemi, dilden ve metinden ayrı bir yerde tuttuğu görülür. Onun asıl sorusu ise az önce de ifade edildiği gibi, söylemin bu özelliklerinin konuşmanın yazılı hale getirilmesi ile birlikte nasıl bir değişime uğradığı ve onun bu andan itibaren nasıl ele alınması gerektiği olmuştur. Ricoeur (1990: 28-31), bu sorulara yanıt vermek suretiyle bize metin'in genel karakteristiğini resmetmekte gecikmez. Sorduğu soruların yanıtları hepimiz açısından zaten oldukça açıktır. Söylem yazıya döküldüğünde, söylemde öncelikle konuşana yöneltilen dikkat, metinde konuşanın ortadan kalkmasıyla artık “söylenen”e yönelecektir. Sözlü söylemdeki konuşmanın yapıldığı anı, yani "şimdi 
burada"lığı yazılı söylemde bulmak mümkün değildir. Böylece Ricoeur, yazarın kastettiği ile metnin söylediğinin, bir başka ifade ile yazarın amacı ile metnin sözel anlamının; söylemin metne, yani konuşmanın yazıya dönüştürülmesiyle tamamıyla birbirinden ayrımlaştığını düşünür. Sözlü söylem ile metin arasında bu bağlamda Ricoeur'ün işaret ettiği bir diğer önemli ayrım da, sözlü söylemin anlamı aktarmak ve güçlendirmek üzere tonlama, konuşma tarzı, mimikler ve jestlerden faydalanabilmesine karşın, yazılı söylemde, yani metnin kendisinde bu unsurlardan faydalanılamamasıdır. Bu noktada Ricoeur, yazılı oluş karakteri dolayısıyla metin ile okur arasına "yorum”un gireceğini düşünür. Burada, Yapısalcı modelin anlamaya doğru yönelmesi söz konusudur. Bu derin bir semantiğe doğru kapıyı bize aralar. Nitekim eleștirel ve derin yorumlara "anlama” ile ilerlenir.

Böylece Ricoeur, gösterge ve cümle üzerinde durarak kendi yorum açıklamasını bu ikisi arasındaki farka dayandırır. Göstergeler bağlamında anlam, onun kendisini diğer göstergelerden ayırdığı noktada ortaya çıkmakta ve Ricoeur buna göstergenin semiotiği adını vermektedir. İfade etme işlevini yüklenen cümle ise Ricoeur'e göre, bir araya getirip birleştirme işleviyle bir amaca gönderme yapar. Ricoeur tam da bu noktada, cümlenin semiotiğinden değil, semantiğinden bahsedilebileceği kanısındadır. Birine, bir şey hakkında bir söz söyleme olarak ortaya çıkan cümle Ricoeur'e göre, dili kullanarak yaptığımız bir gönderme olarak ortaya çıkar. Böylece Ricoeur, dil ve söylemi birbirinden ayırırken, öncelikle onların temel birimlerini gösterge ve cümle olarak ikiye ayırır. Ayrıca bu ayrımdan hareket ederek, konuşmanın bir edim olarak kurulmasının cümlenin sahip olduğu dört dilbilim özelliği sayesinde mümkün olduğunu düşünür. Bu cümle dilbiliminin dört özelliği ise Ricoeur'e göre (1990: 36), aynı zamanda metnin nesnelliğini oluşturan özelliklere de karşılık gelir. Dolayısıyla Ricoeur (1990: 36), burada metnin nesnelliğini, anlamın tespit edilmesi, metnin anlamının yazarın niyetsel amaçlarından ayrımlaşması, belli bir muhatabı değil de evrenselliği temel alması, görünmez, gizli göndermelerde bulunabilmesi çerçevesinde açıklar. 
Metnin taşıdığı bu nesnel özellikler içinde, onun yapısalcılık eleştirisinin merkezine oturan, metnin gizli anlamlara, görünmez göndermelere sahip olabilmesidir. $\mathrm{Bu}$ özellik, metindeki anlaşılması gereken şeyi, metnin arkasında gizli olarak bulunan söylemin ilk hali ya da yazarın niyeti olarak değil, metnin önünde duran, olanaklı bir dünyaya işaret eden yanı olarak görmek gerektiği sonucuna götürür (Göka, Topçuoğlu, Aktay 1999: 85). Böylece metin, yorum yönteminin bize açacağı bir mümkünlükler dünyası olarak görülür.

Metinleri araştırma nesnesi olarak ele alan yorum yöntemi de yorumsama (hermeneutik) olarak karşımıza çıkar. Söylem çözümlemelerinin göstergelerin kendi aralarındaki ilişkilerde anlamın nasıl sabitlenebileceğini araştırdığı noktada, yorumsama yöntemlerinin çok anlamlılıktan yola çıkarak, farklı yorum olanakları üzerinde durduğu görülür. Dolayısıyla yorumsama anlayışında gösteren ve gösterilen ilişkisinin, yapısalcı modelin iddia ettiği gibi durağan değil, aksine devingen bir özellik taşıdığı ortaya çıkar, bu ise anlamlama sürecinin gösterenden gösterene doğru gerçekleşen bir kayma olarak (Sarup 1995: 14) ele alınmaya başlandığını gösterir. Böylece anlamı, tek bir göstergeyi baz alarak açıklama imkanını yitiririz; çünkü bu anlayışta anlam bir gösterenler zinciri boyunca hareket halindedir ve bu zincirde onun yerini tam olarak kestirmek de mümkün görünmemektedir. Göstergenin birbirinden farklı bağlamlarda görünürlük kazanması, gösterilenin, dolaşıma sokulduğu çeşitli gösteren zincirlerinde değişime uğrayacağını ifade ettiğinden, anlamın hiçbir zaman kendisiyle özdeş kalamayacağını söyleyebiliriz.

Nitekim Derrida'nın da (1997) gösterge kavramını incelerken, dilde gerçeğin temsilinin sorunsuz bir şekilde gerçekleştirilemeyecek bir özellikte olmasını, anlamın tamamıyla anlaşılabilecek ve keşfedilebilecek bir şey olmamasına bağladığı görülür. Sadace zihinde değil, insan eylemlerinde de bulunduğunu varsaydığı anlamın, kişilerarası ve öznelerarası olduğunu düşünür. Nitekim Derrida da tıpkı Ricoeur gibi, insan pratiklerinin, yani eylemlerinin de anlam 
içerdiklerini ve dolayısıyla onların da yoruma açık olduğuna değinmekte ve bu bakımdan hiçbir yorumun da tarafsız olamayacağına ayrıca dikkat çekmektedir. Dolayısıyla da Derrida, yorum sürecine, yani metin çözümlemesine ayrıștırmak, parçalarına dağıtmak ve çözmek, kısacası "yapıbozuma” uğratmak üzere yaklaşır ve bunu kendi önyargılarımız üzerine bir düşünüm olarak konumlar. Bu noktada belirtmeden geçmeyelim ki Derrida her ne kadar ideoloji yaklaşımlarının temel soruları olan toplumsalın bilgisinin kavranması, gerçekliğin eleştirel çözümlenmesi sorularının yanıtlarının aranmasını gereksiz bulmuşsa da, ortaya koyduğu yapıbozum düşüncesinin, bastırılmış, ötelenmiş, susturulmuş olanın kendisini açığa çıkarmak adına önemli imkanlar sunan bir yöntem olarak düşünülmesi gerektiğine de ayrıca dikkat çekelim.

Anlama /yorumlama üzerinde duran bir diğer önemli düşünür olan Gadamer'in anlam/yorumlamaya ilişkin tanımı da doğrudan insan edimi ve toplumsal pratiğin nesnelci bir tanımını ifade eder gibidir (Outwaite 2015: 34). Nitekim Gadamer, anlama'nın yorumlamanın temelinde bulunan ana unsur olduğunu ve sahip olduğumuz önyargılarımızın anlama/yorumlamada bilmenin koşulu olarak karşımızda durduğunu düşünür. Bu bağlamda Gadamer anlamayı, sahip olduğumuz önyargıların süreçteki durmaksızın devam eden bir gözden geçirilmesi, açığa çıkarılması böylece de özelliklerinin ortaya çıkarılması olarak görmek gerektiğine dikkat çeker. Dolayısıyla Gadamer'in ortaya koyduğu önyargı kavramının olumsuz bir etkiden çok, anlama sürecini başlatan olumlu bir etkisinin olduğu ortaya çıkmaktaysa da, onun bu ön yargıların üzerinde sabitlenip kalmamanın, onların üzerine gidilmesi gerektiğinin elzem olduğuna dikkat çektiğine de değinmeden geçmeyelim.

Böylece metin çözümlemesinde karşımıza çıkan "yorum” yönteminin, konuyu ele alan her üç düşünür için de ortak olarak paylaşılan özelliğini yakalamış oluruz: Yorumun öznel oluşu, anlama sürecinin açıklanmasında insan bilgisinin nesnelcilik iddialarının iş göremezliği, anlamsal değişmenin kaçınılmazlığı ve bu değişmenin 
dinamiğini içinde bulunulan bağlamın, yani toplumsal dil pratiğinin oluşturmakta olduğudur. Bu düşünceler kapsamında, peşine düşülen amaç da o halde, zihindeki temsillerin açığa çıkarılması değil, yorumlamanın değişkenliğinin dinamiklerini ortaya koymak olarak karşımızdadır. Dolayısıyla gerek anlamın nasıl sabitlendiğinin peşine düşen söylem, gerekse de anlamın değişkenliğine vurgu yaparak, yorumun dinamiklerine yönelen metin çözümlemelerinin ve tartışmalarının ideoloji tartışmalarıyla kesiştiği nokta, gerçekliğin dil aracalığıyla nasıl olup da belli bir tarzda belirlenebiliyor olduğu olmuştur.

$\mathrm{Bu}$ tartışma ekseninde ise ideolojiye, A. Giddens'ın (1991: 21) ideolojinin nasıl kavranması gerektiğine ilişkin öne sürdüğü ve dört yararlı tezden biri olarak işaret ettiği, “ideolojinin peşine dil ve eylem felsefesinin ışığında, dilin dünyamızı tanımlayan bir araç olduğu düşüncesi kapsamında düşülmesi gerektiği ve dolayısıyla da dili bir praxis olarak kavramak gerektiği” anlayışı temelinde yaklaşmayı uygun görmekteyim. Ayrıca, Akbaş'ın (2018: 51) da belirttiği gibi, ideolojinin tanımlanmasında görülen karmaşa bir yana, bir de onun olumlu mu olumsuz mu anlam taşıması gerektiği yönündeki tartışmalara baktığımızda konunun içinden çıkılmaz bir hal almasını önlemek üzere, ideolojiye yaklaşım tarzımızı, bu şekilde dilin, toplumsal pratikle ilişkisini görünür kılan söylem ve metin üzerinden oluşturduğu kuramsal bir çerçeveyle sınırlandırmanın faydalı olacağı da düşünülebilir. Dolayısıyla şimdi üzerinde durmamız gereken, söylem, metin ve ideoloji üçlüsünün gerçekliğin inşasındaki etkileri üzerine olmalıdır.

\section{3. Gerçekliğin İnşası: Söylem, Metin ve İdeoloji}

Söylem ve metin çözümlemelerinin, anlamın sabitlenmesi ve yorumun olanakları konusunda yaptığı belirlemeler dil, toplum ve ideoloji konularını birbirine bağlamada iyi bir tutkal görevi görür. Bu bağlantıyı yakalayan önemli düşünürlerden biri şüphesiz ki, Volosinov olmuştur. 0 , Saussure'ün dile eşsüremli yaklaşımındansa, diyakronik bir tarza yaklaşılmasının daha doğru olduğunu düşünerek, göstergelerin maddiliği konusu üzerinden ideolojiyi ele almaya çalıșır. 
Bu amacı doğrultusunda Volosinov'un, Saussure'ün göz ardı ettiği “söz söyleme”yi, kendi açıklamalarında merkeze aldığı görülür. Böylece dilin, farklı sınıfların onu kullanması ve farklı anlamsal çerçevelere ulaşmaları doğrultusunda, bir sınıf mücadelesi alanı olarak görülmesi gerektiği sonucuna ulaşan Volosinov, anlamı, farklı toplumsal çıkarların çatışması sonucunda elde edilen bir üretim olarak ele almak gerektiğine dikkat çeker (Mumby 1989: 294). Volosinov'un bu düşüncelerinin temelinde, söylemin sembolik olma özelliği dolayısıyla kendisinden başka bir şeye gönderimde bulunuyor olabilmesi, göndergesel alanın potansiyel bir anlam çokluğuna sahip olması ve bu anlamsal yapının ideolojilerin temsiliyet sistemleri olarak, bizim dış dünya ve öteki ile kurduğumuz ilişkilerin temelinde bulunması önemli bir rol oynar. Burada gözden kaçmaması gereken husus, Volosinov'un burada dili bir mücadele alanı olarak belirlerken, bu mücadelenin aynı terimi, sahip olduğu yan anlamlar dolayısıyla farklı anlam ve biçimlerde kullanmak isteyenler arasında gerçekleşmekte olduğuna dikkat çekmek istemesidir (Hall 1994: 90).

Volosinov'un ardından Pecheux'un da anlamı, söylemin dilsel öğeleri arasındaki ilişkiler ile açıklama yoluna giderek, onu söylemsel süreçte üretilen bir ürün olarak tanımladığı görülür. Böylece her ne kadar Yapısalcı modelden hareket etse de, Thompson'ın (1984: 234) da dikkat çektiği gibi, Pecheux kendi modelinde anlamın toplumsal-tarihsel koşullar altında, yani belli bir bağlamda ortaya çıktığına dikkat çekebilmiştir. Dolayısıyla ona göre farklı gruplar aynı dili kullansa da, farklı söylemlere ve bundan ötürü de faklı anlamsal çerçevelere sahip olabileceği gözetilmelidir (Larrain: 1995: 103).

Coward ve Ellis'in (1985: 140-144) ise, psikanaliz ve Marksist kuramdan faydalanarak, dilin de tıpkı ideolojik, siyasal ve ekonomik pratikler gibi bir pratik, bir anlamlandırma pratiği olduğunu, süreç içerisinde ideolojik pratik tarafından işlense de kendine özgü bir gerçeklik alanına da sahip olduğunu savunduğu görülür. Bu örneklerin bize ifade ettiği en temel şey, ideolojinin açıklanmasında, 
artık dilin toplumsal karakterinin ve kullanımının ön plana alınıyor olduğudur. Anlam'ın söylem içerisinde oluşturulmuş bir ürün olarak ele alınması, yani söylemsel formasyonun kendi içerisindeki öğelerle ilişkili bir şekilde ortaya konulması, egemenlik ilişsilerinin de bu öğeler arasındaki ilişkilerin düzenlemesi ve anlamların kendi lehlerine harekete geçirilmesi olarak anlaşılmasının önünü açmıştır. Nitekim Thompson da (1984: 199-200), söylemi ideoloji olarak ele alırken, anlamların inşasını, egemenik ilişkilerinin sürdürülmesi süreci olarak ele alması bunun en çarpıcı örneklerinden biridir. Bu ve buna benzer düşünce formasyonları içerisinde rastladığımız en temel düşüncelerden biri, egemenlik ilişkilerinin, anlamsal süreçleri denetim altına alarak dış dünyanın, öznenin, kısacası tüm gerçekliğin üretimini sağlayabildikleridir.

Örneğin yine Laclau ve Mouffe'nun görüşlerine bakacak olduğumuzda, onların da hegemonik pratiklerin söylem içerisinde, gösterilen ile göndergenin belli bir amaçla bir araya getirilmesiyle mümkünleştiğini ve gösterilen ile göndergenin bu keyfi birlikteliğinde zaten olanın bile gerçek ve olduğu haliyle temsilinin mümkün olmadığını düşündüğü görülür. Dolayısıyla onların anlayışlarında gerçekliğin temsilinin ideolojik olması, dilde gösterilenin gösterenden önce varolmasına ve ona itaatkar bir şekilde bağlılığına gönderme yapılarak açıklanır (Eagleton 1996: 290).

Marksist temelli bu düşüncelere Foucault, önemli bir yeni kuramsal halka ekler. Bu halka, iktidar kavramı tanımlaması bağlamında klasik ideoloji ile post yapısalcı söylem anlayışlarının birbirinden ayrıldığı noktayı da temsil eder. Örneğin Marksist düşünce temelinde Althusser'in yaklaşımında, söylem ile iktidarın bir ve aynı süreçte değerlendirilmesi gerektiği düşüncesi, Foucault tarafından da paylaşılır. Ancak Foucault da süreçlerin aynılığı dolayısıyla iktidarın bir söylem olarak ortaya çıktığı yerde, bireylerin özneler olarak inşasından da bahsetmemiz gerekir (Sarup 1995: 94-98). Klasik ideoloji anlayışları özneleri önceden kurulmuş varlıklar olarak, maddi/nesnel yapıdan türetilen çıkarlarının 
bilincine sahip olma ve bu bilinci dil aracılığıyla dış dünyaya aktarmak suretiyle iktidarı şekillendirebilme özellikleri ile ele alır. Böylece de, ideolojinin insanların kendi gereksinmelerine uygun bir şekilde üretildiği savunulur. Oysa Foucault, öznelerin söylem kavramıla birlikte, dilsel toplumsal pratiklerle üretilen bir söylemsel konum olarak düşünülmesi gerektiği kanaatindedir. Eş deyişle Foucault'da bilginin de, iktidarın da, öznenin de oluşum sürecini söylemin oluşumu, üretimi sürecinde izlemek ve açımlamak mümkündür de denilebilir. 0 halde bu anlayışta, iktidarın sahip olunan bir şey olmayıp, uygulanılan bir şey olduğu ve hepimizin iktidarın mikro düzeylerde yarattığı dilsel etkiler dolayısıyla bu iktidar şebekesi içerisinde çoktan düzenlenmiş katılımcılar olarak yerimizi almış failler olarak bizi belirlediği rahatlıkla ifade edilebilir (Barret 1991: 136).

Tüm bu oldukça özet anlatım çerçevesinde lafzi ve yazılı olmak üzere dil ile olan ilişkilerimizin, toplumsal pratiklerimiz üzerindeki biçimlendirici etkilerine ideoloji tartışmalarıyla birlikte bakmaya çalıştık. Bu noktada, ideolojinin dil ile olan ilişkisini Heck'in (2003: 124) Veron'dan aktardığı şekilde şu tek cümle ile ifade edebileceğimiz kanaatindeyim: "İdeolojiden bahsedeceksek, onu, iletileri ortaya çıkaran anlamsal kurallar sistemi olarak tanımlayabiliriz.” Bu kurallar sisteminin ise gerçekliğin toplumsal inşasında iş gördüğü gözetildiğinde, artık dil, toplum ve ideolojinin birbirine bağlandığı zeminden hareketle hukuka da bakabileceğimiz noktadayız demektir. Dolayısıyla şimdi de dil dolayımından geçen bir toplumsal pratik olarak hukukun, dil üzerinden ideolojiye nasıl bir bağ ile bağlı olduğunu göstermeye çalışalım.

\section{Toplumun Biçimlendirilmesinde Dil, İdeoloji ve Hukuk}

Giriş kısmında da ifade edildiği gibi, dil, tüm dolayımların dolayımcısı olduğundan hukuk alanı da bundan muaf değildir. Kendine özgü norm ve kurallardan oluşan kendine özgü bir toplumsal pratik olan hukuk, bu norm ve kurallarını dilin dolayımında açımlar. Bundan ötürüdür ki hukuk dilin kendine özgü imkanlarından faydalanarak kendi norm ve kurallarını, yani kapsam ve 
alanını belirlerken aynı zamanda onun eksiklik, kusur ve belirsizliklerinden de üstüne düșen payı alır. Ancak hukuk, bundan deyim yerindeyse gocunmaz; dilin getirdiği bu eksiklik, belirsizlik ve kusurları da yine onun imkanları üzerinden, yani yeni tanımlamalar ve yorumlamalar yoluyla aşmayı dener.

Öte yandan hukuk ve dil denildiğinde gözetilmesi gereken bir diğer önemli husus da, toplumun tüm üyeleri gibi hukuk uygulayıcılarının da belli bir uğraktaki dil'in kullanıcısı oldukları gerçeğidir. Manko'nun da (2016: 2) işaret ettiği üzere, hukuk uygulayıcıları da "belirli bir zamandaki belirli bir epistemik somut topluluğun parçaları" olarak düşünülmelidir. Bunu, hukuk uygulayıcılarının, hukuku uygulama șekilleri, yani onu anlama ve yorumlama tarzları bakımından, aldıkları hukuk eğitimi ve içinde bulundukları topluluğun pratikleriyle sınırlandırılmış oldukları şeklinde anlamalıyız. Nitekim onların hukuka ilişkin tahayyüllerini belirleyen şeylerin başında, hukuk eğitimi esnasında aldıkları eğitim, yani bilgiler gelir. Öte yandan yine hukuksal yorumun ontolojik şartları da hukuksal bir ön anlayış olup, o da eğitim sürecinde edindiği sosyal tecrübe ve öğrenme ile şekillenir (Esser 1972: 10). O halde, yukarıda açımlamaya çalıştığımız gibi ideolojinin, mesajları üretmek için göstergesel, yani semantik alanı kullandığını ve bunu da bir bilgi sistemini anlamlar ve göstergeler sistemine dönüştürmek suretiyle gerçekleştiriyor olduğunu hatırladığımızda, hukuk pratiğinin kullandığı belli birtakım tanımlama ve yorumlamaların, mevcut semantik kural ve anlamsal çerçevelerle olan ilişkisine hak ettiği dikkati yöneltmek gerekir.

Öte yandan yine hukuk uygulayıcılarının, hukuku uygulamada yorum metoduna başvurduklarında içinde bulundukları toplumsal pratiğin belirlediği ortak değer ve perspektiflere sadık kalması gerekirliği de bir başka dikkate değer konudur. Çünkü hukuki yorum sürecinde hukuk uygulayıcıları, muhatabı olan kendi hukuk topluluğunu ikna etme sürecinde, kaçınılmaz bir şekilde bu ortak değer ve perspektiflerden de hareket etmek durumundadır. 0 halde, hukuk 
uygulayıcılarının mevcut semantik/göstergesel bir çerçeveyi kullanarak ve içinde bulunduğu hukuksal topluluğun dikkate aldığı değer ve perspektiflerden hareket ederek hukuk sürecini yönettikleri dikkate alındığında, onların hem davanın süreci içerisinde belli bir ideolojinin etkisi altında olabileceklerini hem de davayı sonuçlandırmada gerekçe ve sonucun ibrazı olarak ortaya koyacakları söylemin (lafzi ya da yazılı) yaratacağı etkinin kendisi bakımından da ideolojik olabileceğini düşünmenin doğru bir yaklaşım olduğu kanaatindeyim.

$\mathrm{Bu}$ noktada, anlamların nasıl sabitlendiğine ve göstergelerin çokanlamlılığının nasıl olup da bertaraf edilerek tek vurgulu hale getirilebildiğine yönelik sorular eşliğinde, dikkatimizi hukuk, dil ve ideoloji arasındaki ilişkilere yöneltelim. Bu amaç doğrultusunda, kanımca Stuart Hall'a değinmek ufuk açıcı olacaktır. Nitekim Stuart Hall'un medya çalışmaları yaparken, üzerinde durduğu temel konulardan biri de semantik çerçevenin nasıl birtakım gruplar lehine harekete geçirilebildiği olmuştur. Bu doğrultuda Hall'un, dil ve ideoloji arasındaki ilişkiyi netleştirmede, Volosinov ve Gramsci'nin izinden giderek, ideolojik pratiği, birbirleriyle rekabet halindeki anlamların mücadelesi olarak tanımlaması ise elbette ki, sorduğu şu anlamlı soruların yanıtlarının izini sürmesiyle mümkün olmuştur: "Nasıl oluyor da başat bir söylem, tek açılklama olma yetkisini kendine tanıyor ve alternatif tanımlar üzerinde sınırlamayı ya da yasaklamayı sürdürebiliyor? Betimleme ve açıklama kurumları (kitle iletişim araçları) yeğlenen ya da sınırlandırılan anlam silsilesini sürekli kılmayı nasıl beceriyor? (Hall'dan aktaran Sancar, 2014: 133)" Gerçekten de Hall'un bu sorular eşliğinde ideolojiyi, toplumsal anlamların belirlenmesi alanındaki mücadele olarak tanımlıyor olması, bizim açımızdan da ilginin bir kez daha hukukçu ve dil kullanımı üzerinden hukuk ve ideoloji ilişkisine yönelmesine vesile olmalıdır. Anlamların belirlenmesindeki bu mücadele alanında, hukuk uygulayıcılarının zorunlu olarak kullanmak durumunda olduğu lafzi gerekçelendirmelerde ya da yazılı hukuku temele alarak yaptıkları yorumlamalarda kullanmayı tercih edecekleri semantik çerçeve bakımından, söz 
konusu anlamların belirlenmesindeki mücadele alanında belli bir saf tutuş almış ve alacak olmalarının kaçınılmaz olduğunu görmek gerekir.

Ayrıca, hukuk dilinin de, tıpkı dilin kendisi gibi açık uçlu olduğu, yasa hazırlanırken her muhtemel olayın yasa koyucu tarafından göz önünde tutulmasının imkansızlığı bakımından yasaların her ne kadar kesin ifadeler ile yazılmış gibi görünseler de, bir zorunluluk olarak belli bir muğlaklığı da bünyelerinde taşımaları gerektiği dikkate alındığında ve yine bir olasılık olarak yepyeni bir teknoloji ya da daha önce öngörülememiş bir toplumsal pratiğin mevcut hukuksal çerçeveye uyarlanması gerektiğinde, hukuk uygulayıcılarının bir "yorumlama” edimine başvurmalarının kaçınılmaz olduğuna dikkat çekelim. Bu noktada hukuk uygulayıcılarının zorunlu olarak yapmaları gereken bu yorumlamalarda, belli bir topluma olan aidiyetleri gereği, "belli bir bilgi sisteminin" onlara sunduğu semantik/göstergesel çerçevenin içinde olmak üzere karar verme yetkileri ve hareket etme kabiliyetleri olduğunu da görmek gerekir. Bu durum bile tek başına şuna işaret eder ki: Hukuki hiçbir karar, hiçbir zaman tek başına tamamıyla eldeki hukuki malzemelerle belirlenebilir bir doğaya sahip değildir; bu anlamda da her türden hukuki karar, hukuk uygulayıcılarının hukuk tahayyüllerinin asıl belirleyicisi olan, toplumsal pratikle hem şekillenen (toplumsal pratiğin ve gerçekliğin asli kurucusunun dil olması anlamında), hem de şekillendirilen (dilin semantik çerçevesinin kurulmasında toplumsal bağlamın önemli olması anlamında) dilin, yani semantik kural ve çerçevenin sınırları içinde de şekillenmek durumundadır.

Öte yandan bir noktanın da gözden kaçmaması gerekir ki, o da, hukuk dilinin, dilin doğasından gelen belirsizliği giderme ve hukuki metinlerin sahip olduğu boşlukları doldurma işinin kimi durumlarda, rüşvet, siyaset, hukuk uygulayıcılarının keyfiliği açısından da doldurulabileceğidir. Peki bu durumda hukuk dilinin sahip olduğu bu belirsizlik ve boşlukların giderilip doldurulmasında ideolojinin mi yoksa bu gibi faktörlerin mi rol oynadığına nasıl karar vermek 
gerekir? Hukuk, dil ve ideoloji ilişkisini kurarken, özellikle üzerinde durduğumuz husus hatırlanacak olursa bu ayrımı rahatlıkla yapabileceğimiz kanaatindeyim. Çünkü buradaki tartışmalarda asıl odak noktası, anlamların nasıl olup da birtakım grupların lehine harekete geçirilebildiği ya da anlamın oluşumunun farklı gruplar arasındaki mücadelelerle mümkün olduğuydu. Dolayısıyla belli bir çerçevede ortaya konulan başat anlamın, mikro ya da makro ölçekte "otoriteyi" de temsil edecek baskın bir grubun tercihi olduğunu görmek gerekir. Bu noktada söz konusu otoriteyi, "iktidar, hegemonya, devlet" gibi kavram ya da mekanizmalardan biriyle açıklama tercihini siz okuyuculara bırakmaktayım. Nihayetinde burada dikkatleri çekmeye çalıştığımız şey, hukuk dilindeki belirsizlikleri giderme ve hukuk metinlerindeki boşlukları doldurma işlevinde başat anlamı belirleyenin "otorite" olması ölçüsünde, burada "ideoloji”nin de iş başında olduğudur.

Kaldı ki, bu “otorite"nin hukuksal kavramların anlamlarını belirleme ve hukuksal boşlukları doldurmadaki görevinin yanında, bir başka asli görevinin daha olduğunun da altı çizilmelidir. Bu da, onun her türden mekanizma, uygulama ve pratiğin asli kuruculuğunu üstlenmesinde olduğu gibi, semantik kural ve çerçeveyi kullanmak suretiyle hukuku da oluşturmada, yani yasaları yapmada da işin başında olduğu gerçeğidir. 0 halde belli bir düşünme zincirini izlediğimizde, hukuki değirmenin suyunun başında dahi “otorite"yi görmenin ve bu anlamda da hukukun zaten daha oluşum aşaması itibariyle "ideoloji" ile belli bir ilişki içerisinde olduğunu söylemenin mümkün olduğuna da ayrıca dikkat çekelim. Bu noktada sanıyorum ki, konuyu somut bir örnek çerçevesinde incelemek hukukun dil ile olan bu özel ilişkisinde otoritenin, yani ideolojinin varlığını görünür kılmada faydalı olacaktır. Bu örnekle, otoritenin hem kurucu bir öğe olarak hukuki kavramları nasıl şekillendirmekte olduğunu hem de hukuki yorumlamalarda bu kavramların anlamlarını belirlemede ne şekilde başat bir rol oynayabileceğini görmeye çalışalım. 


\section{1. Kurucu İktidarın Dil Üzerinden İdeolojik Bir Salınımı: İnsan Haklarına “Dayalı" ve "Saygılı"}

Bilindiği üzere, 1982 Anayasası, askeri bir darbenin ardından 1961 anayasasında birtakım değişiklikler yapılmak suretiyle hazırlanmıştır. Ayrıca her ne kadar demokratik asli kurucu iktidar örneği olma iddiasındaysa da, hazırlanma sürecinin içerdiği antidemokratiklik bakımından ağır eleştirilerin odak noktası halini almış da bir anayasadır (Topuzkanamış 2019: 1769). Biz burada bu eleştirilerin, otoritenin lehine sonuçlanır görünen ve bu bakımdan da ideolojik olma özelliği taşıyan kısmı ile ilgili olacağız. Bu bağlamda, 1961 Anayasası'ndan 1982 Anayasası'na geçişte 2. maddenin içerisinde geçen bir sözcügün değiştirilmesinin açtığı yorum farklılıklarının ve bu yorumda ortaya çıkan anlamların otorite lehine nasıl harekete geçirilmekte olduğu üzerinde duracağız.

1961 Anayasa'sının “insan haklarına dayalı” teriminin yerine, 1982 Anayasası'nın 2. maddesinde “insan haklarına saygılı” deyiminin kullanılmış olduğunu bilmekteyiz (Özbudun 2017: 109). Burada görülebileceği gibi, "insan hakları" ibaresi sabit kalmak üzere, ona dayalı olmaktan, saygılı olmaya doğru bir deyiş farklılığı söz konusudur. Buradaki temel tartışma ise, bu iki yazım arasında bir anlam ve içerik farklılaşması olup olmadı̆̆ı yönünde cereyan etmektedir (Tanör ve Yüzbaşığlu 2018: 86). Biz ise burada iki önemli hususa birden dikkat çekmeyi amaçlamaktayız: Bir yandan kurucu iktidarın kendi hukuk dilini yaratmakta olduğuna, diğer yandan da anlamların yoruma açıldığı noktada otoritenin lehine nasıl harekete geçirilebilmekte olduğuna.

İnsan hakları ile ilgili olmak üzere "dayalı" ifadesinin yerine "saygılı" ifadesinin kullanılması ile ilişkili olarak ortaya çıkan tartışmalarda bizi, birbirine zıt iki yorum karşılar. Ancak hemen belirtilmeli ki, bu yorum farkı, anlamsal düzeydeki basit bir değişimden çok, hukuki uygulamada dikkate değer bir fark yaratıyor olması bakımından çok daha dikkate değerdir. Bu yorumlardan ilkine, örneğin Özbudun'a (2017: 109-110) bakılacak olduğunda, bu iki deyim arasında, bir anlatım farkı ötesinde temel bir anlam ve yaklaşım farkı bulunduğunu 
savunmak güçtür. Soysal'a (1997: 188-190) ve Topuzkanamış'a (2019: 17691770) göre ise, burada anlamsal düzeyde yaratılan temel bir yaklaşım farkı söz konusudur ve bu da iki anayasayı birbirinden ayıran tutum farkı ile yakından ilgilidir. Çalışma boyunca, göstermeye çalıştığımız üzere, anlamayı dilsel ifadelerin anlaşılması olarak kavrayacaksak eğer, bu iki farklı dilsel ifadenin bir tema üzerindeki olası sonuçlarını görmezden gelme lüksümüzün olmadığı da hemen anlaşılmalıdır. Öte yandan, unutulmamalıdır ki hukuk yorumu, hukuk normu ve hukuk eylemlerinin anlamlarının anlaşılmasıdır; fakat bu anlamlar da kesin olmayıp her daim şüphelidir (Klatt'tan aktaran Topakkaya 2019: 224). Ayrıca burada bir hukuk metninin oluşturulmasını, yani yasanın yapımını "hukuk eyleminin" kendisinden de ayrı düșünmemek gerekir. Nitekim, hukukun oluşturulma eylemi, hukuka ilişkin tüm eylemleri şekillendirecek olan en temel hukuk eylemimizdir de. 0 halde, ele alınan bu ifadeler kapsamındaki yorum farklılıkları ve onların uygulamalarının ne tür bir değişiklik izlediği dikkatlice irdelenmelidir.

Bunlardan ilk yoruma bakılacak olduğunda, Özbudun'un (2017: 109-110) iddia ettiği gibi eğer "insan haklarına dayanan devlet" ve "insan haklarına saygılı devlet" ifadeleri arasında iddia edildiği gibi köklü bir anlam ve yaklaşım tarzı yoksa ve varolan tek şey, bir üslup farkından ibaret olarak kabul edilecekse, o halde, burada bir yorum ve dolayısıyla da bir uygulama farkından söz etmenin pek de anlamı olmayacaktır. Bizimse buradaki ilgimiz, "anlam" ve "onun farklı uygulamalar için harekete geçirilmesi” olduğundan, ikinci yorumun bizim açımızdan daha dikkate değer olduğunun altı çizilmeli.

Bu gözle bu ayrımlaşmaya baktığımızda, 1982 Anayasası'nda gördüğümüz, insan haklarının, saygı duyulması gereken bir değerler bütünü olduğudur. Ancak açıktır ki, burada insan hakları artık devletin temel dayanaklarından ya da varoluş nedenlerinden biri değildir. Burada devlet öncelikle başka amaçlar için vardır: “Toplumun huzuru, milli dayanışma, adalet anlayışı vb. (Tanör ve Yüzbaşığlu 
2018: 86). Dolayısıyla Soysal (1997: 127), burada önceliğin devlette olduğunu ve insan hak ve özgürlüklerinin de ikincil kılındığını görmek gerektiğine dikkat çeker. Gerçekten de bunun bir örneğini, Anayasa Mahkemesi'nin 1985 yılında verdiği bir kararda görmek mümkündür. Burada “1982 Anayasası'nın 2. Maddesinde, insan haklarına toplumun huzuru, milli dayanışma ve adalet anlayıșı içinde saygılı olunacağı hükmüne yer vermek suretiyle 1961 Anayasası'na nazaran Devlet ve toplumun çıkarlarına öncelik tanınmıştır" ifadesine yer verilmektedir (E. 1984/14, K. 1985/7, k.t. 13.06.1985). Elbette ki bu yorum konuya ilişkin tek yorum olmayacaktır ve değildir de; çünkü yine 1985'te Anayasa Mahkemesi'nin konuya ilişkin farklı bir yorum getirmek suretiyle, Polis Vazife ve Salahiyet Kanununa getirilen değişiklikler ile ilgili kararında Anayasanın “özgürlükçü bir görüşü benimsemiş" olduğu ifadelerine yer verilir (E. 1985/8, K. 1986/27, Kt. 26.11.1986). $\mathrm{Bu}$ yorumu değilleyen bir başka Anayasa Mahkemesi kararı ise 1994'te yeniden karşımıza çıkar ve burada ise özelleştirmeye ilişkin KHK'lerle ilgili yetki yasasının anayasaya aykırılığı saptanırken, 2. maddeye atıfta bulunularak devletin çıkarları merkeze alınıp, otorite yanlısı anayasa yorumu benimsenir (Tanör ve Yüzbaşığlu 2018: 87).

$\mathrm{Bu}$ örneklerde göze çarpması gereken husus, bir ifadenin, ki burada hukuksal bir ifadenin, anlamsal olarak karşılık geldiği şeyin temel hak ve özgürlüklere öncelik tanınmasıyla ya da otoritenin hizmetine koşulmasıyla harekete geçirilebildiğidir. Bir ve aynı hukuksal ifadenin birbirinden farklı bu iki yorumu, elbette ki nihayetinde hukukun temel hak ve özgürlüklerimiz için mi, yoksa otoritenin bekasını gerçekleştirmek için mi temelde bir amaç taşıdığı ya da bunlara verdiği payenin orantılanmasının nasıl yapılacağı konusunda ayrı bir tartışma konusunu da gündeme taşımaktadır; ki bizim için burada önemli olan bu soruyu sorabilmek, eş deyişle hukukun dil dolayımı (anlam ve yorum) üzerinden otorite ve ideoloji ile olabilecek bu türden olası ilişkilerine dikkat çekebilmekti. Dolayısıyla burada bu tartışmaya sadece dikkat çekmek suretiyle yetinmekteyiz. Ancak, artık öyle sanıyorum ki, hem birey olarak her birimizi ayrı ayrı hem de tüm toplumu 
ilgilendiren bir alan olan hukukun aynı zamanda uygulamalı ve sorumlu kılıcı da bir alan olması bakımından, ona ilișkin olan anlamlandırma ve yorumlama pratiklerinin çok daha önemle üzerinde durulması gereken bir konu olduğu açıklığa kavuşmuştur. Çünkü burada açığa çıkan şey, hukukun zaten kendisinin belirliyor olduğu semantik çerçevede kendisine çeşitli (aleni ya da gizli) yorum olanakları da açarak, hak ve özgürlükleri otorite lehine ikincil kılabilme ve hatta bazı durumlarda devre dışı bırakabilme gücü ve yetkisine sahip olabildiğidir.

\section{Sonuç}

Çalışmamızda hukuk, dil ve ideoloji ilişkisini, kendi sınır ve çerçevesine sahip bir gerçeklik olarak hukukun dil, yani anlamlar ile olan inşası ve hukuk dilinin taşıdığı belirsizliğin yoruma kapı açma özelliği üzerinden ele almaya çalıştık. Anlam ve yorum üzerinden açımlanan dil ve ideoloji tartışmalarındaki ortak düşünce, anlamların çoğunlukla otorite ya da güç odaklarının lehine harekete geçirildiği veya anlamın belirlenmesindeki mücadelenin çoğunlukla bu otoritenin ya da güç odaklarının lehine sonuçlanmakta olduğuydu. Bu noktada ilgimizi, hukuk dilinin içindeki anlamlar ve yorum olanaklarıyla, bu olanakların otorite ya da güç odaklarının lehine harekete geçirildiği ölçüde hukukun ideoloji ile olabilecek ilişkisine yönelttik. Bu bağlamda öncelikle dil ve ideoloji ilişkisini, ardından da bu ilişki vesilesiyle hukuk ve ideoloji ilişkisini ele almaya çalıştık. Bu ilişkiler silsilesini ise hem hukukun oluşturulmasında anlamsal çerçevenin bilinçli kurulumuna hem de bu çerçeve içerisinde yorumun olanak tanıdığı mümkün bir anlamın otorite lehine nasıl harekete geçirilebildiğine dair, kendi Anayasamıza ilişkin bir örnek üzerinden somutlaştırarak bağlamına oturtmaya çalıştık. Bu bakımdan, varılan nokta itibariyle dil, ideoloji ve hukuk üzerinden bir farkındalık yaratmış olmayı ummaktayız. Öte yandan çalışmaya dair vurgulanması gereken şey, bu yaratılmak istenen farkındalığın varılmak istenen nihai sonuç olmadığıdır. Çünkü bu farkındalık sadece, bizi yeni sorular sormaya hazır ve hevesli kılmayı başardığı 
ölçüde bir değer ve anlam taşımaktadır. Farkındalık bir "impulsus" olarak iş görebildiğinde değerlidir.

O halde bu itici gücün etkisiyle öncelikle şunu soralım: Modern dünyada vazgeçilmez bir toplum düzenleyicisi halini alan hukuku, Boyle'nin (1984-1985) olmasını arzu ettiği gibi gerçeklikten ayrı bir alan olarak düşünebilmek, yani günlük çatışma ve gerginlikleri, otorite alanı dışında kalacak nötr/tarafsız bir semiyotik hukuk diliyle ifade etmek ne kadar mümkündür? Farklı düşüncelere açık olmakla birlikte, şunu ifade etmeliyim ki, kanaatimce bu en az Leibniz'in Characteristica Universalis'i1 ${ }^{1}$ kadar imkansız görünmekte. Konunun girizgahında hukuk dilinin zaten belli ölçülerde de olsa bilinçli bir muğlaklığa da sahip olduğuna dikkat çekerken, bunu her bir davanın farklı ve benzersiz olma özelliğiyle ve ortaya çıkması muhtemel yeni bir teknoloji ya da toplumsal pratiğin mevcut hukuk çerçevesine oturtulmasıyla ilişkilendirerek temellendirmiştik. Yine aynı bağlam üzerinden, her bir davanın kendi içinde biricik olduğunu gözettiğimizde, olası her bir dava için, ona özgü bir anlamsal çerçevenin oluşturulabilmesinin, yani anlamların hareket etmesini önlemenin, çokanlamlılığı bertaraf etmenin dilin doğası gereği pek imkan dahilinde olmadığı ifade edilebilir.

O halde, hukuku otorite ile olan zorunlu ilişkisinde ${ }^{2}$ tamamıyla kendi doğal işleyişine mi, eş deyişle hukuk uygulayıcılarının insafına mı bırakmak gerekir? Hukuki kararların șekillenmesinde, anlamlarda ve yorumlarda otoritenin aleni ya da gizli ağırlı̆̆ını ortadan kaldıracak hiçbir önlem alınamaz mı? Bu noktada dil, ideoloji ve hukuk üçlemesinde dilin sunacağı imkan ve güçlükleri iyi süzmek gerekir. Bu sorulara tam bir yanıt olmasa da ayakları yere basan bir öneri kanaatimce Balı’dan (2010) gelmekte. Balı, “Hukuka Felsefi ve Sosyolojik Bakışlar

\footnotetext{
${ }^{1}$ Konu ile ilgili daha geniş bir bilgi sahibi olmak için bkz., Atakan Altınörs’ün Felsefe Dünyası 2010/1 Say1: 51, "Bir İdeal Dil Projesi Olarak Characteristica Universalis", s. 67-79.

${ }^{2}$ Otoritenin hukukun oluşturulmasındaki kurucu rolünü ve hukuk dilinde anlamların çoğunlukla otorite lehine hareket etme eğiliminde olduğu göz önüne alındığında, onlar arasındaki ilişkiyi olumsal bir ilişki olarak görmekten ziyade, birinin diğerini var etmesi ve diğerinin de onun otoritesini güçlendirmeye yardımcı olması anlamında zorunlu bir ilişki olarak görmek gerektiği kanaatindeyim.
} 
IV" Sempozyumunda sunduğu bildiri de, konu başlığı da olan "İdeolojilerin Hukuku mu? Hukuk İdeolojisi mi?" diye sormakta ve hukuk ideolojisi kavramını açıklayarak, onu ideolojilerin hukukunun karşısında bir kalkan olarak kullanma amacı gütmektedir. Burada haklı olarak dikkat çekilen şey, hukuk ideolojisinin temel özelliğini adil bir toplum tasarımına hizmet etmesi olarak işaret ederken, onun dayatmacı, çatışmacı, gerginliğe yol açacak her türden süreçlerden uzak tutulması gerekliliği ve hukuksal süreçleri başından sonuna demokratikleştirmek, böylelikle de hukuku toplumsal barışın, çoğulculuğun, uzlaşmacılığın aracı haline getirmek gerektiğidir. Kanaatimce, hukuka dişsal bulduğum bu doğru öneriyi, hukuka içkin olacak bir hukuksal bir yöntem ile birlikte düşünmek son derece önemli ve gereklidir. Bu yöntemi ise yine hukukun temel dolayımlayıcısı olan dil üzerinden açımlamak gerekir. Nitekim, hukukun temel kurucusunun her durumda belli bir otorite olduğu düşünüldüğünde, hukuku en azından oluşum aşamasından sonra kendi iç işleyiş süreçlerinde, sunmakta olduğu anlamsal yapının sadece “adaleti, adil olanı” gerçekleștirmek üzere hareket etmesini sağlamak buradaki temel amaç olmalıdır.

Bu bağlamda hukuk uygulayıcılarının, öncelikle hukuk eğitimleri esnasında yorum metodlarını nasıl kullanmaları gerektiği konusunda iyi bir eğitimden geçirilmeleri şarttır. Hukuk kurallarının yorumlanmasındaki dört temel yorum yöntemi olan, sözel (lafzi) yorum, sistematik yorum, tarihi yorum ve amaçsal yorumun aynı davada eşit değerde tutulması ve hukuk uygulayıcısının yorum faaliyetinde bunların tümünü birden dikkate alması önemli ve gereklidir. Bu metodların hukuk içerisinde nasıl ve hangi sıralamaya göre kullanılması gerektiği hususunda birtakım ayrilmalar mevcutsa da, temele insan hak ve onurunu yerleştirerek onları zedeleyici ve yok sayıcı tutumlardan kaçınıldığı sürece, hukukun bu genel ilkeleri ve adaletin temel kuralları dikkate alınmış olacağından tutarlı bir yorum tarzı zaten kendiliğinden gelişecektir. 0 halde, bir normun ya da metnin anlamını belirleme süreci olarak karşımızda duran hukuksal yorumlamada, anlamsal yapıyı harekete geçirirken, bu hareketin yönünün esas olarak insan hak 
ve onuru olarak tayin edilebildiği ölçüde, onun otorite, yani ideoloji ile olan bağının da olabildiğince zayıflatılabileceğini öngörebiliriz.

Unutulmaması gerekir ki, insan hak, özgürlük ve onuru, bu üçlü sacayağı adaleti nasıl tanımlamak istersek isteyelim, her türden açıklamanın temelinde duran ve ona duyulan ihtiyacı açıklamada iş gören temel kavramlar olarak karşımızdadır. Öyleyse hukuk sistemlerinin üzerinden otoritenin ve güç odaklarının elinin çektirilmesi ve yargıya bir özerklik kazandırılması esas olarak, onun sahip olduğu anlamsal yapının adalete duyduğumuz ihtiyacın temelinde duran insan hak, özgürlük ve onuru yönüne doğru harekete geçmesiyle sağlanabilecektir.

Bunun yanı sıra, bireysel hak, özgürlük ve onurumuzu korumak yanında, toplumsal sorunlarımızı çözmekle de ilgili olan hukuk sistemimizin reform ve düzenlemelere açıldığı noktada, özgür ve barışçll bir tartışma ve müzakere ortamına ihtiyaç duyacağını da elbette vurgulamak gerekir. Nitekim sadece bu yolla, hukuk alanındaki anlamsal çerçevenin bu düzenlenmesinde, anlamların bir mücadelenin sonucu olarak değil, bir müzakerenin, bir uzlaşmanın ürünü olarak karşımıza çıkabileceğini görmek gerekir.

Son olarak şunu ifade etmek gerekir ki, gerçeklik, toplumsal dilin içine gömülüdür; işte bu dil aynı zamanda hukukun da kurucusu olan dil'dir ve bu gerçekliği gömülü olduğu yerden dili kazıyarak çekip çıkarabilecek birileri daima çıkacaktır. İşte o zaman hukukta gömülü olan bu çıplak gerçeklik, adalet değil de otorite olarak karşımıza çıktığında, adalet asıl yerini almakta gecikmemelidir. 0 halde, adaleti başka şeyler uğruna feda etmenin, hele ki otorite ya da güç odakları lehine feda etmenin kimseye bir faydası yoktur; dil onu sakladığı gibi, er geç görünür de kılmasını bilecektir. Martin Luther King'in de dediği gibi, "ahlaki evrenin yayı uzundur ama adalete doğru bükülür" ve "dil”, işte burada her zaman o “son bükücü”dür. 


\title{
An Evaluation of Law and Ideology Relationship over Language
}

\author{
Summary \\ PInar TÜRKMEN BİRLİK \\ Assist. Prof. Dr. \\ İzmir Demokrasi University, Faculty of Arts and Sciences, Department of Philosophy, İzmir, TR \\ ORCID: 0000-0003-1099-5737 \\ pinar.turkmenbirlik@idu.edu.tr
}

\section{Introduction}

Language is our unique medium that we use to understand, tell, comprehend and conceptualize. We come across "language" as an organon to be also dealt with both in any kind of discussions over ideology and in reasoning and applications conducted to ensure justice. Because, it is both the establishing and the established one.

In fact, from whatever perspective the ideology concept is handled, the ideational transformation and paradigm changes wanted to be revealed are tried to be determined with the relational planes to be formed especially with language, meaning, discourse, and context. From this point of view, it is evident that ideology, too, is a concept referring to the areas of thoughts, meanings, and symbolic representations related to the social life itself, just like culture. Ideology reveals its difference from culture at a place where culture points to a partnership and stakeholdership over meaning and symbolic representations by situating itself as a social thinking that happens at a place where social meanings and values contradict one another. Ideology, in this meaning, refers to a conflicting situation in which different forms of consciousness have created within different meanings and interpretations. From this viewpoint, ideology, which we can express as the effort to define social practice in a definite manner, places in a "linguistic" context over the definition and interpretation of the existing one.

Another practice that places in this linguistic context over definition and interpretation problem is law. Law, which we encounter as a social event at first, can find expression as " commands, namely, norms", "court decisions" which belongs to " a certain society", pointing to human-made normative place within the context of positive law (Wacks, 2017: XV). These mentioned law norms and court decisions are conserved within a law text and their basic decisivenesses are found within the decisions to be given by law-makers in view of single events. We witness law with a historical existence just like society itself demonstrates its historical existence within 
these law texts. What makes this possible is that law language emerges as a certain definition and interpretation ground of humans' social practice.

Then, ideology, which we refer to as a determination effort of societal practice in a definite manner, can be said to intersect with law obligatorily on a shared ground because of the effort to define and describe at least the existing one or a phenomenon. In our study, it is aimed to try to problematize the relationship between the law and ideology over the language which is the common ground of them.

\section{Discourse, Text and Ideology: Towards Shaping a Society}

Due to the relationship problem between social thinking and social reality, we witness that a great majority of ideology discussions having to get directed to language are conducted within the frame of expression conducted mostly on the plane of meanings and of textual concepts conducted on the plane of interpretation / hermeneutics conducted by both structuralists and post-structuralists. We have to follow the developments in linguistics in order to track this relationship between ideology and language.

\section{1. Towards the Evaluation of Social with a New Perspective: Instability of Discourse and Meaning}

The discussions in the semiotics, after Saussure and Barthes, evolve from the clear meaning thought as the result of the correct application of language rules into suppressive meanings owned by what is shown and the suppressive meanings to be clarified, into their functioning orders- that is- into searching the opportunities of the interpretation. Thus, it comes to prefer regarding the societal with a new perspective over the expression resolutions. The most important mindfulness created by expression resolutions is that language is an important medium that produces the thoughts directing the behavior of the individual and corporations, in other words, the one that enables the societal life to be shaped.

Also, the discourse analyzes extend their relations in the language plane into sentence and from sentence into utterance and text. Therefore, the discourse approaches based on the main thesis that the meaning has the ability to move within language come to defend not the stability of meaning but its changefulness and emphasize the interpretation as an opportunity provided by this changefulness.

Emphasizing especially the enunciation in discourse analyzes gives chances to new mindfulnesses specific to language. Nevertheless, the examinations on enunciation set aside the studies on language structure, opens a new thinking field on communication features of statement. Thus, the factors that are determinant in a communication find expression as the place of conversation, the time and conditions of it. At this point, it is needed to notice that discourse analysis is directed to meaning flows created by individual language performances depending on these factors. That's why, meaning flows' happening in a definite context and situation becomes the main interest of discourse analyzes. 
In other words, the questions how the meaning is created, to whom it is revealed, what it expresses and what kind of effect it produces places on the center of discourse analyzes. In order to answer such questions, the first question to be replied by the discourse analysts is, at first, the question of under what societal conditions the discourse occurs. However, when ideology is defined as directing the meaning in it to a sense - as creating the effect to produce and multiply the domination relations (Sancar 2014: 136), the concept of power as a focus point having produced these effects have been directed and the relations between discourse and power have come to be problematized. Thus, it has been tried to clarify with what kind of mechanism the power relations work within linguistic and symbolic communication.

\section{2. A New Possibility in Making Sense of Social Practices: Text and Interpretation}

The thinkers having dealt with the concept of text as a searching object seem to first reveal the difference of this searching object from discourse and therefore to feature its specific opportunities. We can count Ricoeur, Gadamer and Derrida among these thinkers having attempted to make examination in this direction taking the text itself as the basis.

The mutually shared feature of this "interpretation" method in text resolution for these three thinkers dealing with the subject is that the interpretation is subjective, the objectivity claims human knowledge are dysfunctional in the explanation of understanding process, semantic change is inevitable and the present context- that is, social linguistic practice- composes the dynamics of this change. Within the fame of these thoughts, the pursued objective is then ahead of us not as revealing the representations in mind but as revealing the dynamics of the changefulness of interpretation. Therefore, both the expression tracing how the meaning is fixed and the point at which discourse analyzes and discussions leading to dynamics of the interpretation emphasizing the changefulness of meaning intersect with ideology discussions have been what on earth the reality can be determined in a certain manner through language.

In the axis of this debate, we find it suitable to approach ideology on the basis of the understanding "that in light of language and action philosophy after ideology, language should be considered within the thought that it is a medium that defines our world and therefore it is necessary to comprehend a language as a praxis", which A. Giddens (1991 : 21) put forward regarding how ideology should be comprehended and pointed out as one of the four useful theses. Within this context, the effects of the trio of expression, text and ideology on the building up of reality should be emphasized.

\section{3. Building up Reality: Discourse, Text, Ideology}

The identifications made by discourse and text analyzes about the fixing of the meaning and interpretation opportunities act as a fine binder in linking the language, society and ideology matters together. So, it is possible to come across many thinkers considering the issue from this perspective. For instance, Volosinov identifies the 
language as a field of struggle and thinks that one term of this struggle is taking place among those who want to use it in different meanings and forms because of the connotations it has (Hall 1994:90).

On the other hand, Pecheux tried to explain the meaning with the relations among the linguistic elements of discourse, defining it as a product made in an expressional process and draws attention to the fact that the meaning emerges under societal-historical conditions, that is, in a definite context.

Coward and Ellis (1985: 140-144) utilized psychoanalysis and Marxist theory, advocating that language is a practice, an interpretation practice just like ideological, political and economic practices. The most basic thing these examples tell us is that the social character and use of language in explanation of ideology are from now on taken to the forefront. The revelation of discoursive formation in relation to the elements in itself causes the dominance relations to be understood as the organization of relations among these elements and as moving the senses in favor of them.

Within this context, considering again the thoughts of Laclau and Mouffe and then Foucault, we notice that they set forth the representation of reality is ideologic, there are linguistic effects produced by the power and hegemony practices are placed in expression.

At this point, I am of the opinion that we can state the relationship of ideology with language as cited by Heck (2003: 124) from Veron with this single sentence: "If we are to talk about ideology, we can define it as the system of semantic rules uncovering the messages." Considering that the system of rules work in societal building up of reality, it means that we are at a point to look at law depending on the ground at which language, society and ideology are linked to one another.

\section{Language, Ideology and Law in Building up Society}

Law, which is a specific social practice with specific norms and rules, demonstrates these norms and rules in the exposition of language, that is, with senses. So, it is necessary to see that law-enforcers, in a struggle field in the determination of senses, are inevitable take certain sides in this struggle from the viewpoint of semantic frame that they will prefer in literal justifications they have to use or in interpretations they make based on written law.

Also, because of the uncertainties in law language and because of the current law frame remains insufficient in some situations, we should draw attention to the fact that law-enforcers inevitable apply an "interpretation" performance. It is clear that this semantic frame they will use in this interpretation performance has to be a semantic frame presented to them by "a certain knowledge system" depending on their involvement in a definite society. This situation alone points out that no lawful decision has a nature that can be identified totally with the materials at hand at any time. The respect to be cared for at this point is that we can talk about ideology here to the point that what determines the dominant meaning is the "authority" in the function of eradicating the uncertainties in law language and filling in the blanks in the 
law texts. Because we notice that this "authority" is on act even in the formation of regulations, we can say that law is related to ideology considering the formation of law. At this point, I think that examining the subject within the frame of a concrete example will be useful in clarifying the existence of authority, namely, ideology in the special relationship of law with language.

\section{1. An Ideological Oscillation of Constituent Power over Language: "Depending on" and "Respectful to" Human rights}

Here, we will deal with the interpretation differences caused by the change of a word in the $2^{\text {nd }}$ article in the transition from 1961 Constitution to 1982 Constitution and how the meanings emerging in this interpretation have been evoked in favor of authority. We know that the saying "respectful to human rights" is used in the $2^{\text {nd }}$ article of 1982 Constitution instead of the saying "depending on human rights" in 1961 constitution (Özbudun 2017: 109). The main discussion here takes place whether or not there is a meaning and content difference between these two editions (Tanör and Yüzbaşığlu 2018: 86). Here we aim to draw attention to the two important respects both: on the one hand to the fact that the constituent power is creating its own law language and on the other hand to how the meanings are used in favor of authority when they are opened to interpretation.

In this mentioned discussion, according to Özbudun (2017: 109-110), it is hard to maintain there is a main meaning and approach difference beyond a narrative alteration. According to Soysal (1997: 188-190) and Topuzkanamış (2019: 17691770), there is a main approach change created at meaning level and this is closely related to the attitudinal difference differentiating two constitutions. What we see in 1982 Constitution is that human rights is a total of values to be respected. Yet, it is clear that human rights here is not one of the main bases or existence reasons of the state. Here the state exists especially for other aims: "Peace of Society, national solidarity, sense of justice etc. ( Tanör and Yüzbaşığlu 2018:86)." Therefore, we agree with Soysal (1997: 1217), considering that the priority here is with the state and human rights and freedom are made secondary.

The respect to be taken into consideration in these examples is that what meaningfully refers to a statement, which is here a lawful statement, can be evoked with prioritizing the main rights and freedoms or with putting it into the service of authority. Our main problem here is that these two different interpretations of one and same lawful statement mainly carry the purpose for our basic rights and freedoms or for conducting the survival of the authority. Eventually, what we have to care for here is that law can open several opportunities for interpretations (public or hidden) for itself, and have the power and ability to make the basic rights and freedoms secondary in favor of authority and to disable it under some conditions.

\section{Result}

In our study, we tried to deal with the relationship of law, language and ideology over the building up of law with language, that is, with meanings and over the 
uncertainty feature of law language to result in interpretations. The common thinking in language and ideology discussions demonstrated over meaning and interpretation was that the meanings were mostly evoked in favor of authority or power focuses or the struggle in the determination of the meaning mostly resulted in favor of this authority or power focuses. At this point we directed our attention to the meanings and interpretation chances in the language of law and to the potential relationship of law with ideology to the extent that these chances of interpretation are evoked in favor of authority and power focuses. In this context, we tried to deal with first the relationship between language and ideology and then, thanks to this relationship, deal with the relationship between law and ideology. We tried to contextualize this sequence of relationships by concreting over an example regarding our Constitution both related to the conscious establishment of meaningful framework in building up law and related to how a possible meaning enabled by the interpretation in this frame is evoked in favor of authority. From this viewpoint, we hope to have created a mindfulness over language, ideology and law in consideration of the point we have arrived. On the other hand, what should be emphasized regarding the study is that the mindfulness desired to be produced is not the final result wished to be reached. Because, this mindfulness carries a value and meaning to the extent that it manages to make us ready and eager to ask new questions. Mindfulness is valuable when it works as a "driving force".

What we see in our study is that the basic founder of law is a certain authority. From this point of view, the main aim here must be to evoke law in an attempt to realize "justice, fair" in its inner processes at least after its foundation phase.

In this context, it is obligatory for law-enforcers to receive a good training about how they must use the methods of interpretation during their law education. There are some disagreements about how and in which order these methods should be used in law. But, we can say that a consistent manner of interpretation will automatically develop as long as we place human rights and honour to the center, avoiding harmful and ignoring attitudes of this principle. In that case, we can predict that in evoking a meaning structure in lawful interpretation in front of us as a process to determine the meaning of a norm or text, the link of this act with authority, that is, ideology can be weakened as much as possible to the extent that the direction of this act is appointed as human rights and honour in main. Nevertheless, gaining a self-determination to jurisdiction can be provided mainly when the meaning structure it has evokes towards human rights, freedom and honour which are in the center of our need to justice. Also, eventually, we must say that our law system regarding the solution of our social problems needs a free and peaceful discussion and debate environment, besides protecting our individual rights, freedom and honour at the point where it is opened to reforms and arrangements.

Finally, it must be said that reality is embedded in social language; this language is at the same time the founder of law and there will always be someone to pull out this reality from where it is embedded by digging out language. In this case, there is no use in sacrificing justice for the sake of other things, especially in favor of authority and power focuses; language is sure to make it visible just as it hides it. As Martin 
Türkmen Birlik, P. Dil Üzerinden Hukuk ve İdeoloji İlişkisinin Bir Değerlendirilmesi. Kaygi, 20 (2), 2021, 440-477.

Luther King said, "the arc of moral universe is long but it bends towards justice" and here "language" is always that "the last bender". 


\section{KAYNAKÇA | REFERENCES}

Akbaş, K. (2018). İdeoloji Olarak Hukuk. Hukuk Kuramı, 5 (3), 50-71.

Anayasa Mahkemesi Kararları: Esas: 1984/14, Karar: 1985/7, Karar Tarihi: 13.06.1985; Esas: 1985/8, Karar: 1986/27, Karar Tarihi: 26.11.1986. Erişim Tarihi: 30.04.2021, (https://karararama.yargitay.gov.tr/YargitayBilgiBankasilstemciWeb/).

Balı, A. Ş. (2010). İdeolojilerin Hukuku mu? Hukuk İdeolojisi mi? HFSA, Hukuk Felsefesi ve Sosyolojisi Arkivi (19. Kitap, ss. 142-157). İstanbul: İstanbul Barosu Yayınları.

Barret, M. (1991). The Politics of Truth: Ideology from Marx to Foucault, Oxford: Polity Press.

Boyle, J. (1984-1985). The Politics of Reason: Critical Legal Theory and Local Social Thought. University of Pennsylvania Law Review, 133, 685-780.

Coward, C. R. ve Ellis, J. (1985). Dil ve Maddecilik (çev. E. Tarım). İstanbul: İletişim Yayınları. Routledge.

Dant, T. (1991). Knowledge, Ideology and Discourse. London and New York:

Derrida, J. (1997). Of Grammatology (trans. by G. C. Spivak). Baltimore and London: Johns Hopkins University Press.

Eagleton, T. (1996). İdeoloji (çev. M. Özcan). İstanbul: Ayrıntı Yayınları.

Esser, J. (1972). Vorverstandnis und Methodenwahl in der Rechtsfindung. Frankfurt am Main.

Giddens, A. (1991). Four Theses on Ideology. Ideology and Power in the Age of Lenin in Ruins (ed. A. Kroker \& M. Kroker, pp. 21-24). Montreal: New World Perspectives.

Göka, E., Topçuoğlu, A., Aktay, Y. (1999). Önce Söz Vardl, Yorumsamacllk Üzerine Bir Deneme (2. Basım). Ankara: Vadi Yayınları.

Hall, S. (1994). İdeolojinin Yeniden Keşfi: Medya Çalışmalarında Bakı Altında Tutulanın Geri Dönüşü. Medya Íktidar Ídeoloji (der. ve çev. M. Küçük, ss. 169-195). Ankara: Ark Yayınevi.

Hart, H. L. A. (1994). The Concept of Law (with a postscript ed. by Penelope A. Bulloch \& J. Raz, 2nd Edition, pp. xii-315). Oxford: Clarendon Press.

Heck, M. C. (2003). The Ideological Dimensions of Media Messages. Culture, Media, Language (eds. S. Hall, D. Hobson, A. Lowe \& P. Willis, pp. 120-126). Routledge. 
Larrain, J. (1995). İdeoloji ve Kültürel Kimlik. İstanbul: Sarmal Yayınevi.

Manko, R. (2016). İdeoloji ve Hukukta Yorum: Birkaç Kuramsal Düşünce (çev. Artun Mimar). Birikim Dergisi. Erişim Tarihi: 09.04.2021, (https://birikimdergisi.com/guncel/8088/ideoloji-ve-hukukta-yorum-birkackuramsal-dusunce).

Mumby, D. K. (1989). Ideology and the Social Construction of Meaning: A Communication Perspective. Communication Quarterly, 37 (4), 291-304.

Outwaite, W. (2015). Hans Georg Gadamer. Çağdaş Temel Kuramlar (der. Quentin Skinner, 2. Basım, ss. 33-57). İstanbul: İletişim Yayınları. Yayınları.

Özbudun, E. (2017). Türk Anayasa Hukuku (17. Basım). Ankara: Yetkin

Ricoeur, P. (1990). Anlamlı Eylemi Bir Metin Gibi Görmek (çev. Taha Parla). Toplum Bilimlerinde Yorumcu Yaklaşım, İstanbul: Hürriyet Vakfı Yayınları.

Sancar, S. (2014). İdeolojinin Serüveni, Yanlış Bilinç ve Hegemonyadan Söyleme (3. Basım). Ankara: İmge Kitabevi Yayınları.

Sarup, M. (1995). Postyapisalcllık ve Postmodernizm (çev. A. Baki Güçlü). Ankara: Ark Yayınları. Yayınları.

Soysal, M. (1997). Anayasanın Anlamı (11. Basım). İstanbul: Gerçek

Tanör, B. ve Yüzbaşığlu, N. (2018). 1982 Anayasasına Göre Türk Anayasa Hukuku (17. Basım). İstanbul: Beta.

Thompson, J. B. (1984). Studies in the Theory of Ideology. Cambridge: Politiy Press.

Topakkaya, A. (2019). Hukuk Hermeneutiği, Hukukta Anlama ve Yorumlama Sanatı . Ankara: Adalet Yayınevi.

Topuzkanamış, Ş. E. 1982 Anayasasında Temel Hak ve Özgürlükler. D.E.Ü. Hukuk Fakültesi Dergisi, 21, 1767-1793.

Wacks, R. (2017). Hukuk Felsefesine Kısa Bir Giriş (çev. Engin Arıkan, 7. Basım). Ankara: Tekin Yayınevi. 